\title{
The Spanish Energy Transition into the EU Green Deal: Alignments and Paradoxes
}

\author{
José Antonio Peña-Ramos ${ }^{1,2, *(\mathbb{D})}$, María del Pino-García ${ }^{3}$ and Antonio Sánchez-Bayón ${ }^{4, *(D)}$ \\ 1 Faculty of Social Sciences and Humanities, Universidad Autónoma de Chile, Providencia 7500912, Chile \\ 2 Department of Political Science and Public Administration, Faculty of Political Sciences and Sociology, \\ University of Granada, 18071 Granada, Spain \\ 3 Program of Governance and Global Affairs, Leiden University, Turfmarkt 99, \\ 2511 DC The Hague, The Netherlands; delpinogarciamaria@gmail.com \\ 4 Department of Business Economics (ADO), Applied Economics II, and Fundamentals of Economic Analysis, \\ Legal \& Social Sciences School, Rey Juan Carlos University, 28033 Madrid, Spain \\ * $\quad$ Correspondence: japramos@ugr.es (J.A.P.-R.); antonio.sbayon@urjc.es (A.S.-B.); Tel.: +34-657219669 (J.A.P.-R.)
}

check for updates

Citation: Peña-Ramos, J.A.; del Pino-García, M.; Sánchez-Bayón, A. The Spanish Energy Transition into the EU Green Deal: Alignments and Paradoxes. Energies 2021, 14, 2535. https://doi.org/10.3390/en14092535

Academic Editors: Alessia Arteconi, Antonio Sánchez-Bayón, Estrella Trincado, Jesús Alberto Valero-Matas and Rafael Rávina-Ripoll

Received: 7 March 2021

Accepted: 22 April 2021

Published: 28 April 2021

Publisher's Note: MDPI stays neutral with regard to jurisdictional claims in published maps and institutional affiliations.

Copyright: (c) 2021 by the authors. Licensee MDPI, Basel, Switzerland. This article is an open access article distributed under the terms and conditions of the Creative Commons Attribution (CC BY) license (https:// creativecommons.org/licenses/by/ $4.0 /)$.

\begin{abstract}
Climate change, clean energy transition, the energy security quest, and international relations have triggered the revival of renewable energy as a solution to these problems. Nowadays, there is an energy transition where renewable energies bring geopolitical changes in a world where fossil fuels are becoming less relevant. This article aims to assess how the transition influences Spain's energy relations with other countries regarding electricity and its sources, in alignment with the European Green Deal. In order to do so, its current energy situation, the renewable energies development and its energy import-export relations are examined. The results show that despite progress in green regionalization through more electric interconnection, little difference is to be found in traditional relations with fossil fuel countries exporters, but more are the contractions in Spanish energy economic policy, as here is explained.
\end{abstract}

Keywords: geopolitics; renewable energies; energy transition; EU Green Deal; political economy

\section{Introduction}

This paper is based in preview researches [1,2], refocused for the case of Spain's transition into the EU Green Deal framework [3]. In December 2018, the Intergovernmental Panel on Climate Change (IPCC) warning about the catastrophic effects of the global temperature rising to $1.5^{\circ} \mathrm{C}$ acted as a wake-up call for global society [4]. Popular demonstrations proliferated across the World, urging governments to take decisive action in order to address climate change and adopt a new kind of political economy in energy issues [2,3]. The European Parliament declared a climate emergency along with more than 30 countries [5]. In 2019, the European Commission led by Ursula von der Leyen announced the European Green Deal [6], which constitutes the core strategy of the European Union (EU) to tackle climate change and ultimately achieve continental climate neutrality, thanks to an ambitious energy transition plan and a reemergence of renewable energies (RES) use.

Spain has recently put forward an ambitious transition strategy within the EU framework. The Integrated National Energy and Climate Change Plan (NECP) establishes the following core targets for 2030: a $42 \%$ of RES in the energy final use; to ramp up the generation of domestic renewable electricity to $74 \%$; and increasing energy independence by reducing hydrocarbon imports from the current $73 \%$ to $61 \%$, saving up to 75,379 million euros [7].

The COVID-19 pandemic and the subsequent global lockdown $[8,9]$ have catalyzed some recent observable trends in the energy sector. Despite pollution already being back at its usual levels, the tangible decrease-reaching an absolute decline of $7 \%$ during April-May [10]—sped up the decision-making process towards a low-carbon emission 
economy with a higher presence of RES. Even the EU recovery plan to rebuild post-COVID scenario [11] with eco-boosting measures, allocates at least $25 \%$ of EU funds to fight climate change and striving to decarbonize the energy sector [12]. In view of current developments, one may wonder the following: Is a RES-dominated world possible? Would it entail changes in the traditional energy suppliers? Or will the prevalence of fossil fuels render renewable geopolitics irrelevant?

Although calculations estimate an increase of global fossil fuel consumption in the short-medium term, some indicators point at a paradigm shift [13-15]. In a world where fossil fuels are bound to disappear, both net consumer and exporter countries must assess their options to safeguard their future energy supply. Spain, despite its distinct energy situation, is foreseen as one of the greatest beneficiaries of the energy transition due to its still untapped renewable potential and its resources optimization plan. According to the GeGaLo Index, it will rank 38th out of 156 monitored countries based on fossil fuel dependence and reserves, the availability of RES, governance, and potential for conflict [16]. Provided that in a $100 \%$ renewable world new conflict and cooperation patterns will have emerged, it is an interesting exercise to observe what changes are already taking place in the current hybrid system, moving away from fossil fuels, and to what extent Spain is living up to its commitments to the Green Deal [3].

This article aims to provide a closer approach to the complexity of RES and their impact in the energy transition and relations with other states. The paper explores the measures Spain plans to implement according to the European Green Deal and other geopolitical interests. The main hypothesis is that such an increase in RES has prompted an energy regionalization through the expansion of electric interconnections with neighboring countries. In view of a greater need of electricity to meet the increasing integration of RES, we also argue that Spain could accelerate its imports from key fossil fuel providers towards alternative partners with a lesser risk of political instability so as to guarantee energy supply in the medium term (because Spain has a secular energy dependence). In this way, we provide a general approach to the Spanish emergent energy landscape considering the gradual rise in RES, with special attention to the electric sector; explain the main differences between RES and fossil fuels that involve geopolitical shifts on a global scale; and use the data of energy exchanges to examine the alterations in relationships with other countries.

\section{Literature Review}

There is no generally accepted definition of geopolitics, but as this paper focuses on the mutual influence of geographical factors and political processes [16-18], in this sense, geopolitics is linked to access and control of natural resources, from rivers to oil fields. With the occurrence of the Industrial Revolution, coal emerged as the engine of the economy, and in the mid-20th century, it became inextricably associated with the geopolitics of oil and gas [17].

Energy geopolitics developed as a distinct discipline, understood as the way countries influence one another through supply and demand [18]. Given the undeniable nexus between energy security and national security, it is hardly surprising that governmental institutions elaborated the first research projects on this field. Despite the novelty conferred to the study of RES in recent publications, the US National Research Council already presented a thorough investigation on RES in 1962. In it, geophysicists such as King Hubbert from the Shell Company analyzed continuous power sources-particularly solar energy — and their possible transformation for human use [19]. Years later, the 1973 oil crisis and the subsequent oil price volatility encouraged the exploration of alternative sources to mitigate the energy dependence and its political consequences, exemplified by a NASA project to develop wind turbines.

In 2002, the International Energy Agency defined renewable energies as 'those derived from natural processes that are replenished constantly' [20]. These include electricity and heat generated from solar, wind, hydropower, and geothermal resources. Germany and the Benelux countries championed the use of the former two during the first decade of 2000, 
which fostered an in-depth study of their geopolitical implications, prompting several debates on the topic.

In their first approach, many authors extrapolated the dynamics of conventional energies to the geopolitics of renewable energies by replacing dependence on fossil fuels as a source of conflict with that of rare-earth elements, critical for the development of infrastructure [21]. Conversely, other authors claim that the inexhaustible and decentralized nature of RES a priori would lead to more peaceful geopolitical interactions, as they may be exploited by more countries, eventually resulting in a more equitable world [22].

International bodies, noteworthy examples being the IEA or the International Renewable Energy Agency (IRENA), have developed multiple energy and scenario models. However, some authors warn against the inaccuracy of such predictions, which tend to be more modest than the actual changes taking place [23].

Although there is widespread consensus about the fact that a world running on RES would be less prone to conflict than the present status quo, this has resulted in an inclination to think of them as clean energies also in geopolitical terms [24]. However, we are in a new cycle where we still rely on the main commodity from the last century. Recent works advise that the overlap between two different energy regimes will mitigate vulnerabilities on one side while engendering tensions on the other [25].

The transition towards RES will cause a geopolitical and strategic rearrangement that will result in winners and losers. Generally, the consensus about a negative impact of the decline of fossil fuels on petrostates is unanimous [26]; Algeria, Libya, Russia or Egypt, are among the countries deemed to be most vulnerable due to their high exposure to the energy transition [27], which will force them to adapt to the new reality or else, to risk losing their geopolitical significance.

Opinions differ significantly regarding winners. While some assume that net importers will be at an advantage since hydrocarbon sales revenues do not subsidize their economy, Stegen [28] asserts that only those with a high autonomy and export capacity on top of potential renewable energy will take the lead.

In contrast to this background, it becomes evident that a systematic analysis of the energy transition is problematical to say the least. Therefore, in this article, we combine Scholten and Bosman's systemic model (which reflects the changes derived from a greater presence of RES) with the theoretical insights from the decline of fossil fuels and its effects on exporter countries. To this end, a brief overview of the differences between conventional energy and RES will be provided.

\subsection{Differences with Conventional Energies and Their Geopolitical Implications}

As mentioned earlier in the introduction, RES features conflict and cooperation patterns that differ from the existing ones. Unlike fossil fuels (limited and highly concentrated), free, inexhaustible, and geographically distributed energy sources enable their simultaneous exploitation by multiple countries, reducing their energy vulnerability. Since access is not restricted to a handful of states, it reduces the possibility of energy weaponization for political purposes [29].

There are nonetheless some drawbacks. Their low energy density requires the occupation of vast field extensions to install power plants in a profitable way. While fossil fuel plants depend on a steady supply but yield a stable production, non-manageable renewable energy systems - namely wind and solar energy - present a high risk of intermittency. Consequently, a higher total installed power is needed in order to meet the demand during low-availability periods. Likewise, the pursuit of energy independence based on RES to ensure the security of supply not only comes across as utopian in the short term but also as counterproductive. The so-called 'renewable rentierism' - which maximizes exports and disincentivizes imports as the latter are considered to defeat the ultimate independence goal- would undermine much-needed cooperation in a sector where storage difficulties and output variability calls for the establishment of interconnections for the surplus exchange with other countries [24]. 
Yet the fundamental difference is whereas countries have competed to control oil and gas sources, when it comes to RES it is desirable to belong to a network. Paradoxically, energy security increases when the source is available for all countries, and load shedding is prevented, transforming dependence into interdependence [30].

It would be logical therefore, that said network is integrated by similar countries that share energy vulnerability. In this regard, the energy loss suffered during transport would limit its exchange to a regional scenario at the expense of trading agreements with far-flung countries. Such a continental scenario requires a governance model over a competitive one, as strategic behaviors come at a high cost [31]. Despite what may occur with oil and gas (O $\& G)$, a country that aims to blackmail another one by depriving it of energy supply would only fail to recover its initial investments, as current difficulties in storage capacity and the lack of alternative grids would lead to wasted potential energy. In addition, another participant in the grid while revealing the other country as an unreliable partner could easily supply the targeted country. The interdependence elaborated by Nye and Keohane's liberalism theory dissuades from adopting this type of strategic behavior. Thus, we assume that energy security increases with a greater exchange between countries. Therefore, the loss of power of traditional fossil fuel suppliers that the distinction between the consumer and the net exporter will begin to blur [18].

The model assumes that the geographical and technical characteristics of energy systems largely shape their interstate energy relations, in line with the most classical notion of geopolitics. In the case of RES, the sources are the most 'geographical' aspect, given that their location and nature remain unchanged over time. As for their exploitation, nowadays the capital investment is conversely proportional to the learning curve of technology. As a result, the initial costs are increasingly lowered to the point that they are already the most competitive efficiency wise, ahead of fossil and nuclear energy [32].

Furthermore, in RES the marginal cost of producing one more unit of a product tends to zero. Despite the relatively high initial capital investment, the cost of operations is negligible since once the power plant is installed the system works driven by the energy source throughout its life, without the need for relocation in search of more deposits [24]. Likewise, although intermittence increases volatility, its price is not linked to other commodities such as oil and gas, and thus it may be more predictable.

Regarding energy distribution, electrical networks and interconnections gain prominence as power plants must be close to the primary source and connect production centers with those of consumption. Fossil fuels require either oil or gas pipelines, which necessitate a large investment of time and capital, with a fixed layout, or oil tankers, whose routes are easier to redirect but are exposed to bottlenecks [33]. On the other hand, the transport of RES is limited and requires greater integration into the electrical system, and despite their apparent immobility, they allow exchange with other countries through high-voltage direct current connections (HVDC)—which are easier to install—or interconnections.

Hence, the technical and geographic aspects of RES condition the structure of the electricity markets and their relationship with those countries that are sufficiently interconnected. Unlike the oil and gas market, where the World supply is characterized by being in the hands of oligopolies, RES increases competition from national and international operators. The fact that electricity can be imported from nearby countries compels companies to present more appealing offers [34]. At this point, the interconnection capacity with other electrical systems becomes paramount. This arrangement allows a greater amount of renewable energy to be exported to countries with higher prices. Likewise, it reverses the flow when the lack of readily available RES forces importing energy from other countries with different atmospheric conditions, exchanging electricity on a seasonal basis [35]. Thus, market integration is correlated with electricity exchanges, interconnections, and lines, which leads to a geopolitical evolution of unidirectional supply of oil and gas pipelines to networked communities [12].

Therefore, the boost of electricity implies a greater interaction at local and regional level to the detriment of exchanges with more remote countries. The integration of elec- 
tricity networks with neighboring countries will therefore lead to the emergence of new energy interdependencies and trading partners.

\subsection{The Decline of Fossil Fuel Exporters}

Consequently, the transition would set aside the geopolitics of fossil fuels, placing gas, coal, and oil-exporting countries in a delicate position due to their scarce economic diversification. A specialization in oil and gas exports hinders the mitigation of dwindling revenues from such resources because these countries are not equally developed in other areas of trade, and it can lead to economic strain when fossil fuels are no longer profitable. This so-called rentier strategy ceases to be effective from the moment that export revenues do not cover public spending, causing economic erosion and political instability at the domestic level. The lack of income can be a threat multiplier resulting in civilian conflict or massive migration. In this sense, the Middle East and North Africa (MENA), they are deemed to be particularly exposed due to their high dependence on fossil fuels, heightened by their fragile state condition, as epitomized by the Arab Springs of 2011.

\subsection{Other Controversial Issues and Future Lines of Research}

There are other main geopolitical issues concerning a high penetration of renewables, like 'access to critical materials' and 'cybersecurity' [21]. The access to critical materials is important for PV (such as tellurium, indium, silver etc.), wind (rare earth materials for magnets), and storage solution (e.g., lithium) and geopolitical concerns will likely focus on securing these materials. Another important issue is cybersecurity, sharing sensitive information and designing storage operations. The access to relevant resources is discussed in the community in the context of the energy-water-food nexus, and the energy types are categorized along land and water footprints. There are more topics related with the performance of RES in Spain according to the European Green Deal [3], but it will be object of other papers and future lines of research.

\section{Materials and Methods}

This article analyses the evolution of the Spanish energy landscape, with a higher presence of RES and its impact on interstate relations. To this end, we observe two paramount aspects in the transition from a hydrocarbon-based energy cycle towards one based on RES: first, the relation with neighboring countries that already have direct interconnectors with Spain, in line with a more electrified economy; second, with Spain's main oil \& gas providers, which constitute the bulk of the domestic energy mix. It must be highlighted that most of the final uses of oil are divided between the transport sector and oil products, two sectors that are difficult to replace by renewable energies at present. Other uses, such as heating (less common in Spain) and cooling, they are supplied by electricity derived from combined cycles and cogeneration, where the most widely used primary source is natural gas. The timeframe will cover the period following the Paris Agreement, as it is a binding agreement for emission reduction that provided the basis for the Green Deal, and inevitably involves the restriction of fossil fuels' consumption. Information has been gathered from global (AIE, BP) and national (Repsol, APPA, IDAE) energy yearbooks, annual statistics (REE), monographic works, as well as the 2015 National Energy Security Strategy and the 2017 ESN and Statistics from CORES and Red Eléctrica de España (REE).

Although climate change and RES are closely intertwined, the former exceeds the scope of this research and it is thus excluded. Other more technical aspects related to efficiency or energy intensity, infrastructure, or technology are not covered since a more strategic overview is sought in this paper.

The study has been divided into several sections for which the information collected ranges from 2015-the year in which the Paris Agreement was signed - to 2019, as this is the last year for which complete information is readily available. The year 2020 has been left out intentionally since it would distort the trends. For the Spanish energy background, energy dependence and electrical and gas interconnections are examined; Secondly, the 
development of RES in power generation and installed power plants, exports, and the electricity balance; Thirdly, a double section showing those countries whose exports of oil and gas to Spain have been over $5 \%$ in the last 5 years to observe their variation and contrast it with their associated degree of political instability, following a model on political instability per countries from the Chatham House.

Although there is data on exported renewable electricity-which will be explained in the next section-It must be noted that these exports are not generated by 100\% renewable energy sources. This value rather indicates that an identical volume of RES to that exported has been generated due to the fact that it is impossible to determine its origin once it has been transformed into electricity and the unfeasibility of building specific transmission lines for each type of energy.

To facilitate understanding of trade variations, import and export volumes are expressed as percentages of the total for the year in question, since expressing the variation in the nominal volume of imports would be misleading as it would not consider the alterations in total fuel demand within a year.

\section{Results}

\subsection{Energy Profile of Spain}

The National Energy Security Strategy of 2015 describes the Spanish energy landscape as unique, and such distinction has several dimensions. Spain is a net consumer with a high energy dependence-which regardless of the decline from its historical maximum of $81.3 \%$ in 2008 to $73.4 \%$ in 10 years-is still much higher than the European average, which currently stands at $54 \%$ [7]. Notwithstanding the obvious disadvantage that this entails, the high diversification of its energy mix both in terms of source and country of origin adds resilience to the system and reduces the risk of vulnerability to sudden changes in supply.

Beyond that, it remains an energy island. The Spanish electrical system partially meshes with the Portuguese grid (forming the so-called MIBEL Iberian electrical system); with Morocco, extending to Algeria and Tunisia; and with France, which in turn is linked with the Central European and Nordic electric rings. Currently, the Spanish market shares 11 electrical interconnection lines with Portugal, eight with France, and two with Morocco which became operational in 1997 and 2006 respectively, interconnecting Spain and North Africa. These are shown below in Figure 1.

Although practically integrated with the Portuguese electricity market, this only constitutes an interconnection ratio of $2.8 \%$ for Spain with the rest of the EU [36]. According to Entso-e the Franco-Spanish border is one of the greatest congestion points within the panEuropean electricity system. The few electrical interconnections limit Spain's integration into the Union's single energy market, hindering its transition, although substantial efforts have recently been made to mitigate this vulnerability by building an interconnection with France in 2015, the first since 1982.

Regarding natural gas, Spain has six interconnections: in Navarre and Irun with the French electrical system; in Tui and Badajoz with the Portuguese system; and with its major gas supplier in North Africa, Algeria, through a gas pipeline linking Tarifa through Morocco (the Maghreb gas pipeline) and another one with Almeria through Medgaz. These latter interconnections, paired with its location and its regasification capacity, made a solid candidate out of Spain to become the next EU gas hub, as it can receive LNG from both the Gulf of Guinea and Latin America and has seven of the 23 regasification plants in the EU [37]. The PNIEC favors the use of LNG as "in the case of the gas system, it is considered a priority to optimize the use of the already existing interconnection capacity to facilitate access to other gas sources and advance towards the convergence of prices, before undertaking new infrastructures" [7]. 


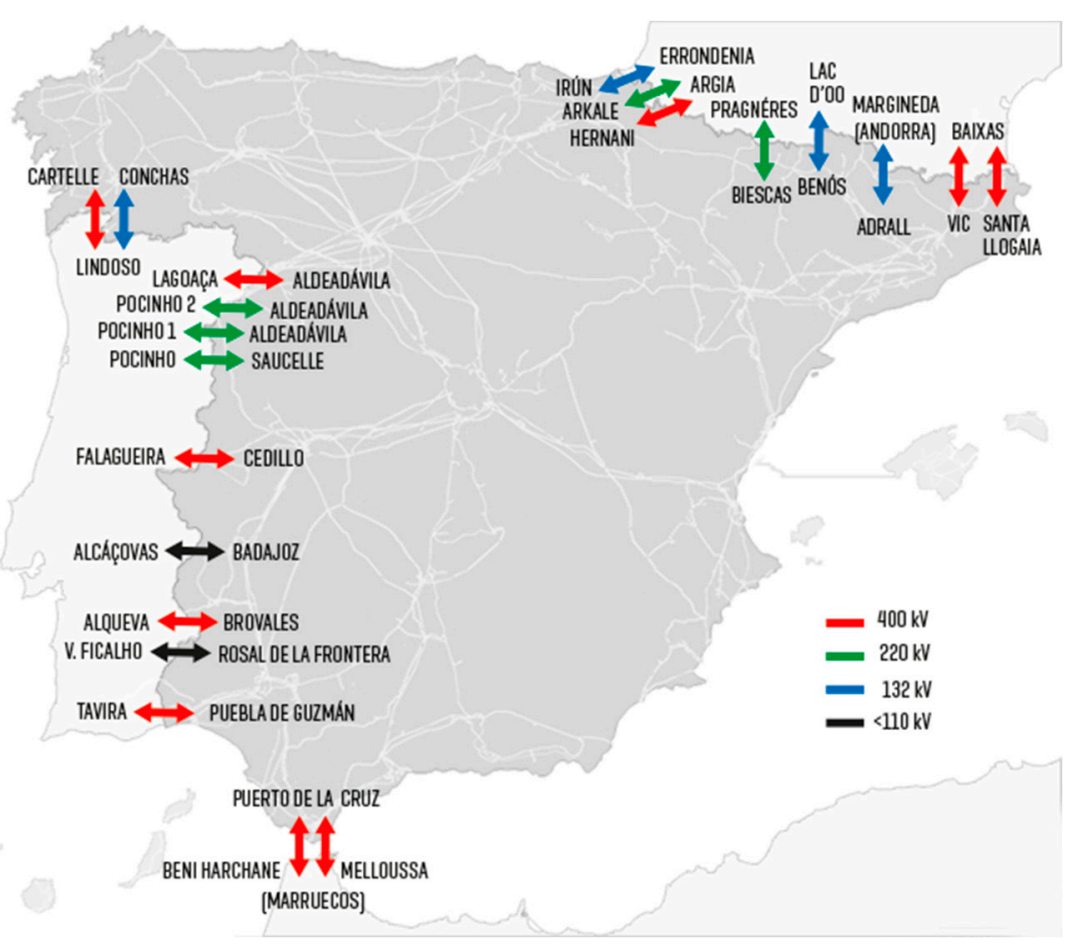

Figure 1. Map of cross-border electricity interconnections in Spain [36].

\subsection{The Challenge of the EU}

Already in 2002, the European Council stipulated in Barcelona that Member States should reach a threshold of $10 \%$ interconnection-i.e., import capacity vs. installed generation power-between MS to meet the growing volume of renewable electricity and enhance its stability. After 2004, the Iberian block was reinforced considerably thanks to the development of programs to build new generating plants.

According to the Energy Union (2015), EU policy aims inter alia to ensure a competitive and viable market and an increasingly synchronous network. In December 2018, the target for interconnections between European electricity systems was raised to $15 \%$, as well as a $32 \%$ increase of RES in total consumption by 2030 [38]. The new connections would not only make it possible to offer lower prices to consumers and help meet electricity demand in national markets but would also facilitate the supply of renewable electricity to other states. Moreover, the promotion of interconnections contributes to increasing the RES electricity consumption by encouraging the development of RES in peripheral countries to meet long-term decarbonization objectives [39]. In this sense, the EU has promoted the Emissions Trading System (ETS) to limit $\mathrm{CO}_{2}$ emissions through financial penalties for companies that fail to comply.

The EU devises cross-border infrastructure plans to unite energy systems between Member States (Figure 2). These Projects of Common Interest (PCI) aim to advance the achievement of the internal energy market and the decarbonisation of the economy in accordance with the commitments made in the Paris Agreement. In the fourth PCI list published in November 2019, four interconnections - three with France and one with Portugal—were listed as part of the North-South Priority Electricity Corridor (NSI West Electricity):

- The 'Bay of Biscay' project, which connects the Basque Country with Aquitaine (France) with an investment of 570 million euros. This $370 \mathrm{~km}$ submarine cable would increase the exchange capacity from 2800 to $5000 \mathrm{MW}$ until achieving a 5\% interconnection, and its commissioning is planned for 2026-2027.

- The Central Pyrenees Project, comprising two new interconnections: Aragon-Atlantic Pyrenees, and Navarre-Landes. In total, it would represent an increase in interconnection capacity of 8000 MW for 2029-2030. 
- Interconnection between the North of Spain and Portugal connecting Galicia with the Portuguese region of Minho. The additional $400 \mathrm{kV}$ attained through a conventional aerial interconnection would achieve the complete integration of the Iberian market, but also the penetration of RES by increasing the exchange capacity to $3.2 \mathrm{GW}$.

- Other projects that have been rejected included gas interconnections with Northern Africa.

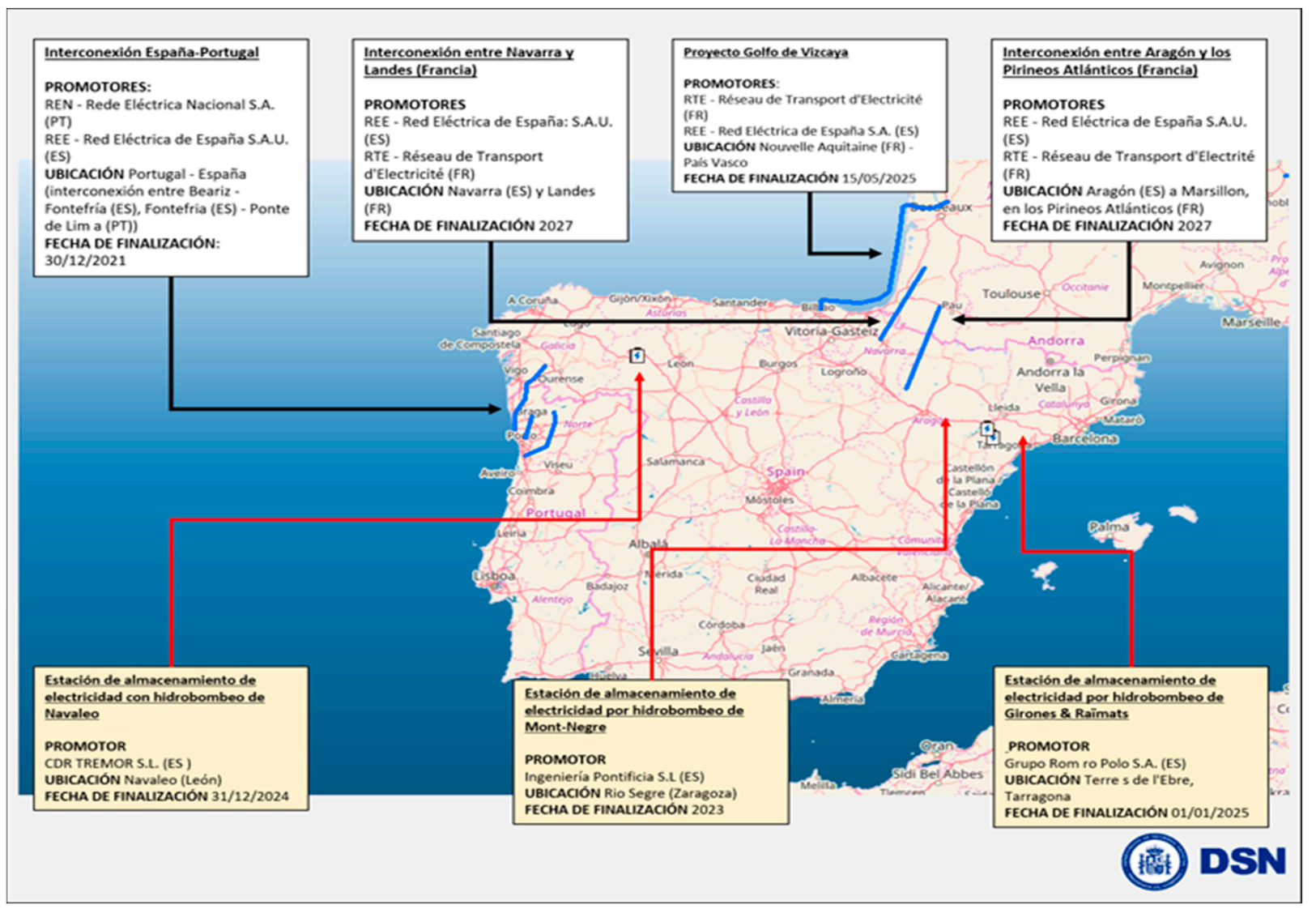

Figure 2. Plan to increase interconnections in Spain of the fourth list of PCI [40].

As for the electrical interconnections with Morocco, those remain the only links between the EU and North Africa to date (new PCI include plans for a submarine cable between Sicily and Tunisia, to be commissioned by 2022), and it allows the flow between Algeria, Tunisia, Morocco, and Spain. In February 2019, a memorandum was signed by a third electric cable to be installed and become operational before 2026. The MoU was activated in last June, although Ceuta and Melilla, located on the African continent, are excluded from these interconnection plans.

\subsection{RES Development}

Traditionally, at a global scale, coal and natural gas -and to a lesser extent nuclear energy- have been predominantly used for electricity generation. As observed in Table 1, the installed renewable power has gradually increased until it eventually outweighed non-renewable power for the first time in 2019: 
Table 1. National installed power per energy type in MW.

\begin{tabular}{ccccc}
\hline Energy Type & $\mathbf{2 0 1 6}$ & $\mathbf{2 0 1 7}$ & $\mathbf{2 0 1 8}$ & $\mathbf{2 0 1 9}$ \\
\hline Combined cycle & 26,670 & 26,670 & 26,284 & 26,284 \\
\hline Coal & 10,004 & 10,004 & 10,030 & 9683 \\
\hline Nuclear & 7573 & 7117 & 7117 & 7117 \\
\hline Non-renewable thermal/co-generation & 5966 & 5802 & 5728 & 5678 \\
\hline Pure pumping & 3329 & 3329 & 3329 & 3329 \\
\hline Fuel + Gas & 2490 & 2490 & 2490 & 2447 \\
\hline Non-renewable waste & 496 & 496 & 490 & 490 \\
\hline Total non-renewable & 56,528 & 55,908 & 55,468 & 55,028 \\
\hline Wind & 23,001 & 23,082 & 23,545 & 25,847 \\
\hline Conventional and mixed hydropower & 17,030 & 17,028 & 17,046 & 17,085 \\
\hline Photovoltaic solar energy & 4683 & 4685 & 4712 & 8913 \\
\hline Thermal solar energy & 2304 & 2304 & 2304 & 2304 \\
\hline Renewable thermal energy/other renewables & 870 & 872 & 877 & 1078 \\
\hline Renewable waste & 160 & 160 & 160 & 160 \\
\hline Hydroelectric & 11 & 11 & 11 & 11 \\
\hline Total renewable energy & 48,059 & 48,142 & 48,655 & 55,398 \\
\hline Total & 104,588 & 104,051 & 104,124 & 110,427 \\
\hline Source Own elaboration from REE data [41] & & & &
\end{tabular}

A total amount of $6743 \mathrm{MW}$ of green energy has been added, rising $13 \%$ from the previous year, exceeding for the first time the threshold of half of the electrical installed power, $50.1 \%$. This surge was mainly due to a greater activity of wind power (2254 MW) and photovoltaic solar power (4201 MW). These sources are growing the most and at the fastest rate respectively, the latter experiencing a $63 \%$ rise in newly installed power. In contrast, the non-renewable power plants have either come to a halt (nuclear, combined cycle, and non-renewable waste) or have decreased (coal, fuel and gas, and cogeneration). Despite all this, the combined cycle continues to possess the greatest installed capacity, with 26,284 MW.

However, in the case of electricity generation, non-renewable energy sources are significantly superior to renewable ones, as observed in Table 2:

Nuclear energy (21.4\%) the combined cycle $(21.2 \%)$, and to a lesser extent, cogeneration $(11.4 \%)$, constitute the bulk of non-renewable generation, as opposed to wind (20.8\%) and hydro energy $(9.5 \%)$, highly conditioned by rainfall. Far behind is solar energy, which barely amounts to $5.5 \%$, and is growing at a slow pace. The fuel most used to produce electricity in Spain in 2019 has therefore been natural gas (combined cycle and cogeneration technologies; $33 \%$ altogether), followed by nuclear energy. What can be observed is a total collapse in the use of coal in electricity generation on a national scale. As for what percentage of renewable generation has been destined for export, we obtain the information from Figure 3:

Exports of renewable electricity-Certified through Guarantee of Origin (GOs)-, they have suffered a decrease compared to 2018, largely due to insufficient rainfall which has reduced hydraulic electricity generation. Nonetheless, there has been a considerable increase since 2017, when the amount of certified energy almost tripled (Figure 4).

As for the amount of renewable electricity for export, according to the IEA, it is the third-largest exporter in RES, representing 23\% of production in 2019 (UNEF). The vast majority was destined for Norway in 2019 (25,900 GWh), well ahead of France (1200 GWh), Portugal (700 GWh), and Germany (500 GWh). Figure 5 shows the electricity exchange, which has recorded an import balance for the fourth consecutive year: 
Table 2. Percentage of renewable and non-renewable generation in Spain (\%).

\begin{tabular}{cccccc}
\hline Energy Type & $\mathbf{2 0 1 5}$ & $\mathbf{2 0 1 6}$ & $\mathbf{2 0 1 7}$ & $\mathbf{2 0 1 8}$ & $\mathbf{2 0 1 9}$ \\
\hline Nuclear & 20.4 & 21.4 & 21.2 & 20.4 & 21.4 \\
\hline Combined cycle & 10.9 & 11.1 & 14.1 & 11.5 & 21.2 \\
\hline Co-generation & 9.4 & 9.9 & 10.8 & 11.1 & 11.4 \\
\hline Coal & 19.7 & 14.3 & 17.2 & 14.3 & 4.9 \\
\hline Fuel + Gas & 2.4 & 2.6 & 2.7 & 2.6 & 2.2 \\
\hline Non-renewable waste & 0.9 & 1.0 & 1.0 & 0.9 & 0.9 \\
\hline Turbine & 1.1 & 1.2 & 0.9 & 0.8 & 0.6 \\
\hline Total renewables & 64.8 & 61.4 & 67.7 & 61.6 & 62.5 \\
\hline Wind & 18.0 & 18.2 & 18.3 & 19.0 & 20.8 \\
\hline Hydropower & 10.6 & 13.8 & 7.0 & 13.1 & 9.5 \\
\hline Photovoltaic solar & 3.1 & 3.0 & 3.2 & 3.0 & 3.5 \\
\hline Thermal solar & 1.9 & 1.9 & 2.0 & 1.7 & 2.0 \\
\hline Other renewables & 1.3 & 1.3 & 1.3 & 1.4 & 1.4 \\
\hline Renewable waste & 0.3 & 0.3 & 0.3 & 0.3 & 0.3 \\
\hline Total non-renewable & 35.2 & 38.6 & 32.2 & 38.4 & 37.5 \\
\hline Own & 1 & & & &
\end{tabular}

Source. Own elaboration from REE data [41].

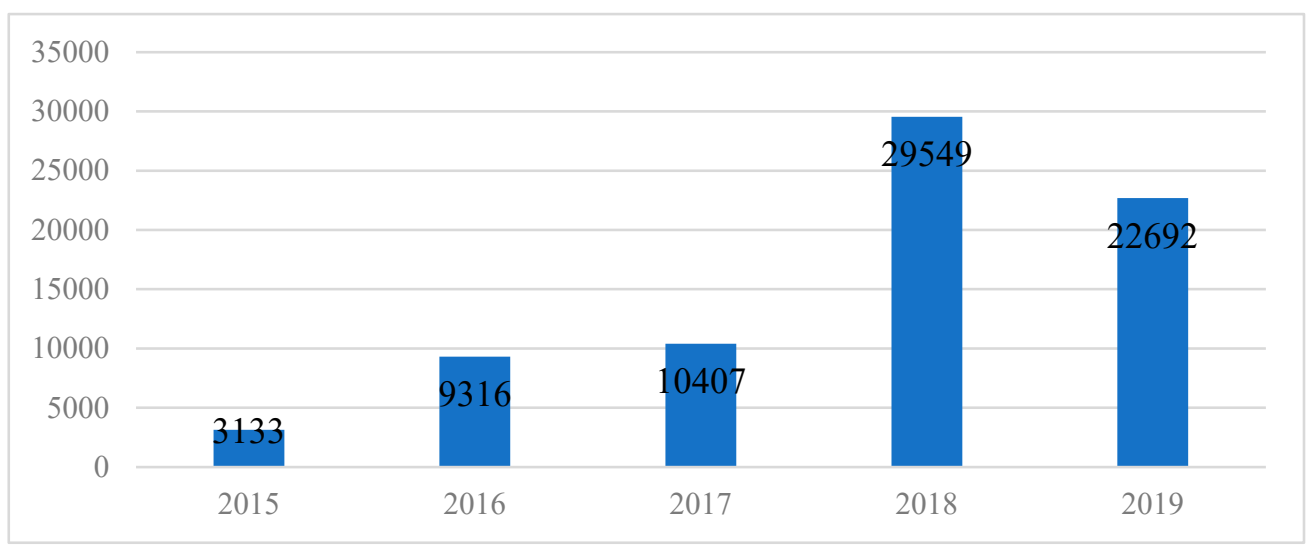

Figure 3. Guarantees of origin sold to the EU by Spain 2015-2019 (in GWh) [42].

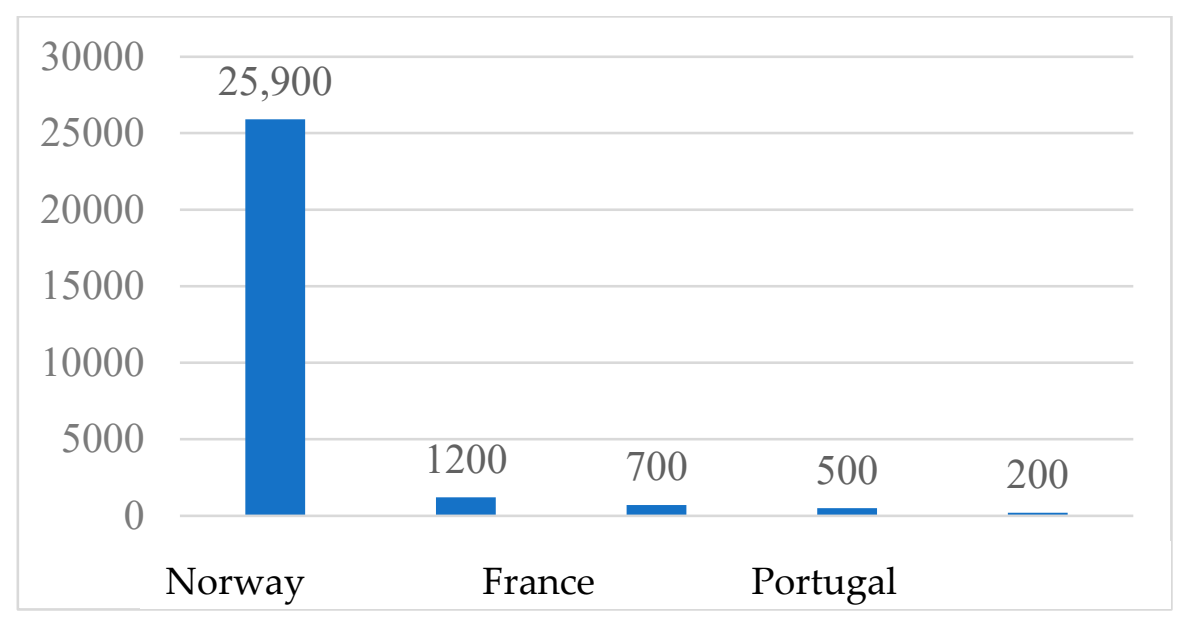

Figure 4. Export destination country of GOs in GWh (2019) [43]. 


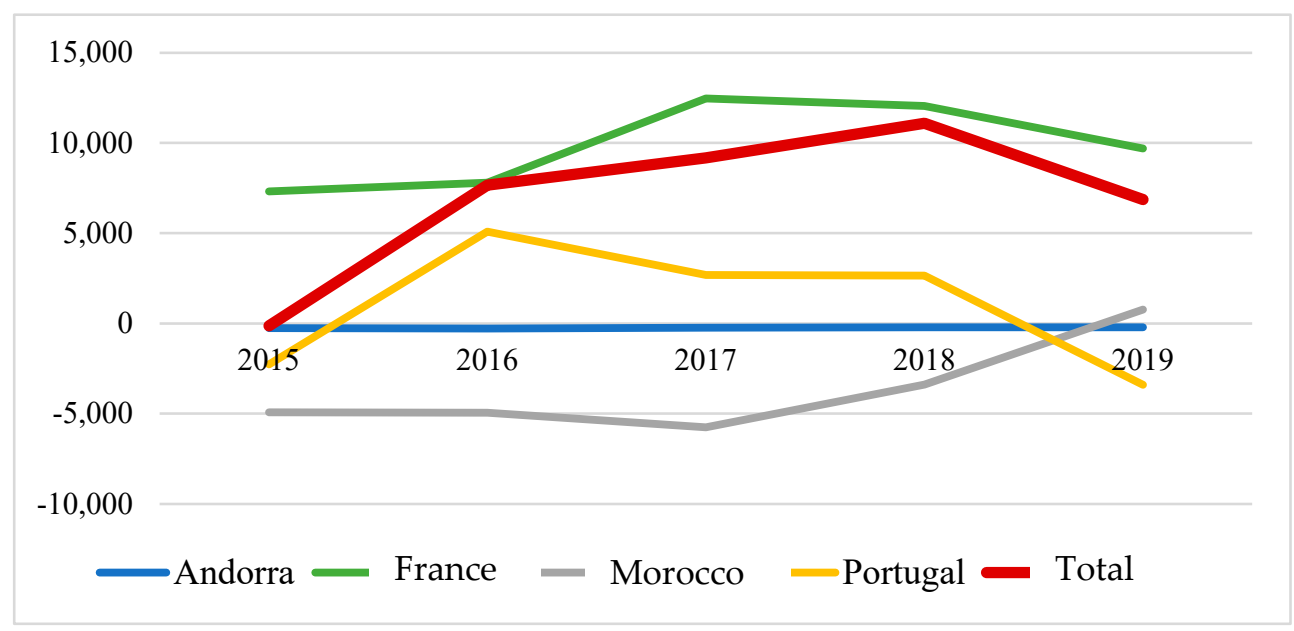

Figure 5. Electric balance per country in GWh (2015-2019). Own elaboration from REE data [41].

In 2019 there is a decrease in the net import balance compared to 2018. Since 2015, the last year in which Spain registered a net export balance, it has significantly increased its dependence on imports from France and moderately from Portugal, the two countries with which the bulk of electricity exchange takes place. France remains a net importing country with $9697 \mathrm{MW}$. However, last year there were two significant changes in the trend: exchanges with Portugal led to an export balance for the first time in four years $(-3399 \mathrm{MW})$, while Morocco exported for Spain for the first time in its history with $773 \mathrm{MW}$.

\subsection{Oil Imports}

While oil demand in 2019 contracted by $2 \%$ over the previous year, there has been a $2 \%$ increase since 2015. As seen in Table 3, Nigeria, Mexico, and Saudi Arabia maintain stable growth, accounting for between $12 \%$ and $17 \%$ of oil demand in 2019 , slightly increasing their percentages since 2015. Specifically, Saudi Arabia experiences a sharper variation from 2015 than Nigeria and Mexico.

Table 3. Percentage of crude oil imports in relation to the total in selected countries (2015-2019).

\begin{tabular}{cccccccccc}
\hline Imports (\%) & Angola & Libya & Nigeria & Mexico & Saudi Arabia & Iraq & Iran & Russia & $\begin{array}{c}\text { Total } \\
\text { (Million Tons) }\end{array}$ \\
\hline 2015 & 8.98 & 2.48 & 16.59 & 13.51 & 10.53 & 5.89 & 0 & 6.18 & 64,726 \\
\hline 2016 & 4.66 & 4.21 & 12.64 & 14.39 & 10.27 & 8.09 & 3.92 & 7.91 & 64,171 \\
\hline 2017 & 3.91 & 8.29 & 14.37 & 14.69 & 9.67 & 6.15 & 6.65 & 3.39 & 65,958 \\
\hline 2018 & 3.98 & 10.52 & 15.19 & 13.88 & 11.09 & 6.92 & 7.24 & 1.51 & 67,586 \\
\hline 2019 & 3.23 & 12.83 & 16.89 & 14.22 & 12.44 & 7.94 & 0 & 2.40 & 66,303 \\
\hline $\begin{array}{c}\text { Variation } \\
(2015-2019)\end{array}$ & $-5.8 \%$ & $10.4 \%$ & $0.3 \%$ & $0.7 \%$ & $2 \%$ & $2 \%$ & N/A & $-3.8 \%$ & $2 \%$ \\
\hline
\end{tabular}

Source. Own elaboration from CORES data [44].

Libya on the other hand is experiencing an extraordinary increase (10.4\%) from $2.5 \%$ to almost $13 \%$ in just 5 years. As for the countries that have noted a significant and gradual decline in demand for crude oil, these are Angola $(-5.8 \%)$ and Russia $(-3.8 \%)$, which will represent barely $3.23 \%$ and $2.4 \%$ of exports, respectively, in 2019 .

By geographical area, Africa-specifically Libya and Nigeria-is positioned as the main importing continent, accumulating $38 \%$ of total imports over all these years. There is also an increase in Latin American imports, which have risen from 10\% to 25\%. Mexico has become a stable importer to the detriment of Europe and the Middle East, largely due to 
the interruption Iranian imports at present, given that despite having contributed to the supply of crude oil for 3 years, it returned to $0 \%$ after a sharp decline in 2019.

\subsection{Natural Gas Imports}

Natural gas is one of the cleanest sources of combustion, emitting half the $\mathrm{CO}_{2}$ of coal and $30 \%$ less than oil, and it is the ideal source of support in achieving the energy transition, in line with the commitments made at the international level. Besides the gradual increase of gas imports of $15 \%$ in the last 5 years, it must be noted that, for the first time, liquefied natural gas imports exceeds those of natural gas, as shown in Table 4:

Table 4. Natural gas and LNG imports as a percentage of total imports in selected countries (2015-2019).

\begin{tabular}{|c|c|c|c|c|c|c|c|c|c|c|c|c|}
\hline \multirow{2}{*}{ Imports } & \multicolumn{2}{|c|}{$\begin{array}{l}\text { Algeria } \\
\text { (Total) }\end{array}$} & \multirow{2}{*}{$\begin{array}{c}\text { Nigeria } \\
\text { LNG }\end{array}$} & \multirow{2}{*}{$\begin{array}{c}\begin{array}{c}\text { United } \\
\text { States }\end{array} \\
\text { LNG }\end{array}$} & \multirow{2}{*}{$\begin{array}{c}\begin{array}{c}\text { Trinidad \& } \\
\text { Tobago }\end{array} \\
\text { LNG }\end{array}$} & \multirow{2}{*}{$\begin{array}{c}\text { France } \\
\text { NG }\end{array}$} & \multicolumn{2}{|c|}{$\begin{array}{l}\text { Norway } \\
\text { (Total) }\end{array}$} & \multirow{2}{*}{$\begin{array}{c}\text { Russia } \\
\text { LNG }\end{array}$} & \multirow{2}{*}{$\begin{array}{l}\text { Qatar } \\
\text { LNG }\end{array}$} & \multicolumn{2}{|c|}{$\begin{array}{l}\text { Total } \\
\text { (GWh) }\end{array}$} \\
\hline & LNG & NG & & & & & LNG & NG & & & LNG (\%) & NG \\
\hline \multirow{2}{*}{2015} & \multicolumn{2}{|c|}{59.70} & \multirow{2}{*}{11.90} & \multirow{2}{*}{0} & \multirow{2}{*}{3.50} & \multirow{2}{*}{3.50} & \multicolumn{2}{|c|}{8.82} & \multirow{2}{*}{0} & \multirow{2}{*}{9.34} & \multicolumn{2}{|c|}{36.4} \\
\hline & 11.56 & 48.15 & & & & & 2.19 & 6.63 & & & 41.72 & 58.28 \\
\hline \multirow{2}{*}{2016} & \multicolumn{2}{|c|}{56.83} & \multirow{2}{*}{14.48} & \multirow{2}{*}{0} & \multirow{2}{*}{2.01} & \multirow{2}{*}{2.15} & \multicolumn{2}{|c|}{10.54} & \multirow{2}{*}{0} & \multirow{2}{*}{7.94} & \multicolumn{2}{|c|}{36.4} \\
\hline & 9.19 & 47.63 & & & & & 2.38 & 8.17 & & & 42.05 & 57.95 \\
\hline \multirow{2}{*}{2017} & \multicolumn{2}{|c|}{48.30} & \multirow{2}{*}{12.73} & \multirow[b]{2}{*}{2.19} & \multirow{2}{*}{1.33} & \multirow[b]{2}{*}{4} & & & & & 38.9 & \\
\hline & 6.88 & 41.42 & & & & & 2.57 & 7.33 & 0 & 10.01 & 47.25 & 52.75 \\
\hline & & & & & & & & & & & 39.1 & \\
\hline 2018 & 4.30 & 47.03 & 11.74 & 0.86 & 6.19 & 2.93 & 1.68 & 7.47 & 2.49 & 9.63 & 42.67 & 57.33 \\
\hline & & & & & & & & & & & 41.8 & \\
\hline 2019 & 2.89 & 30.20 & 11.46 & 11.03 & 7.51 & 7.01 & 1.76 & 4.75 & 8.51 & 11.69 & 57.58 & 42.42 \\
\hline $\begin{array}{c}\text { Variation } \\
(15 / 19)\end{array}$ & & & $-0.4 \%$ & N/A & $4 \%$ & $3.5 \%$ & & & $\mathrm{~N} / \mathrm{A}$ & $2.3 \%$ & $15 \%$ & \\
\hline
\end{tabular}

NG: Natural Gas. LNG: Liquefied Natural Gas. Source. Own elaboration from CORES data [44].

Algeria continues to be the main exporter of total natural gas with $33.08 \%$ in 2019, although it has suffered a significant drop of $26 \%$ in the volume of imports since 2015 when it accounted for almost $60 \%$ of total imports. Other countries experience more moderate variations, with a greater presence of American countries: while Trinidad and Tobago slightly increased its LNG contribution, the United States emerged in 2017 to supply 11\% of LNG demand. Nigeria remains stable at $11.5 \%$, and Qatar, which consolidates itself as the main LNG exporter, slightly above Nigeria. Finally, in line with the trend in the United States, Russia should be mentioned, as it almost tripled its contribution from 2018 to 2019 (8.5\% of total gas imports).

\section{6. (In)Stability of Exporting Countries}

The capacity of the abovementioned countries to face the future decline of the fossil fuel market is linked to their political instability. Such relationship is shown in Figure 6, with the positive value being more unstable than the negative value (values have been multiplied by -100 to facilitate interpretation of the relationship with exports):

In this figure, the correlations between the total fossil fuels exports and political instability evince mixed results. It is clear that Libya (95\%), and Iraq $(100 \%)$, two of the most fossil fuel-dependent economies, present extreme political instability, far above the rest of the countries, except for Nigeria, where this percentage is $94 \%$. In general, the OPEC countries from which Spain has recently imported oil-Angola, Saudi Arabia, Libya, Iraq, Nigeria-show greater instability than the others, although in the first two this is less noticeable. In contrast, countries whose percentage of hydrocarbons is lower in exports tend to have greater political stability in relative terms (France, Mexico, United States, Trinidad and Tobago). Norway, and especially Qatar, stand out as atypical examples 
of political stability, despite having a significant percentage of fossil exports, $56 \%$, and $89 \%$, respectively.

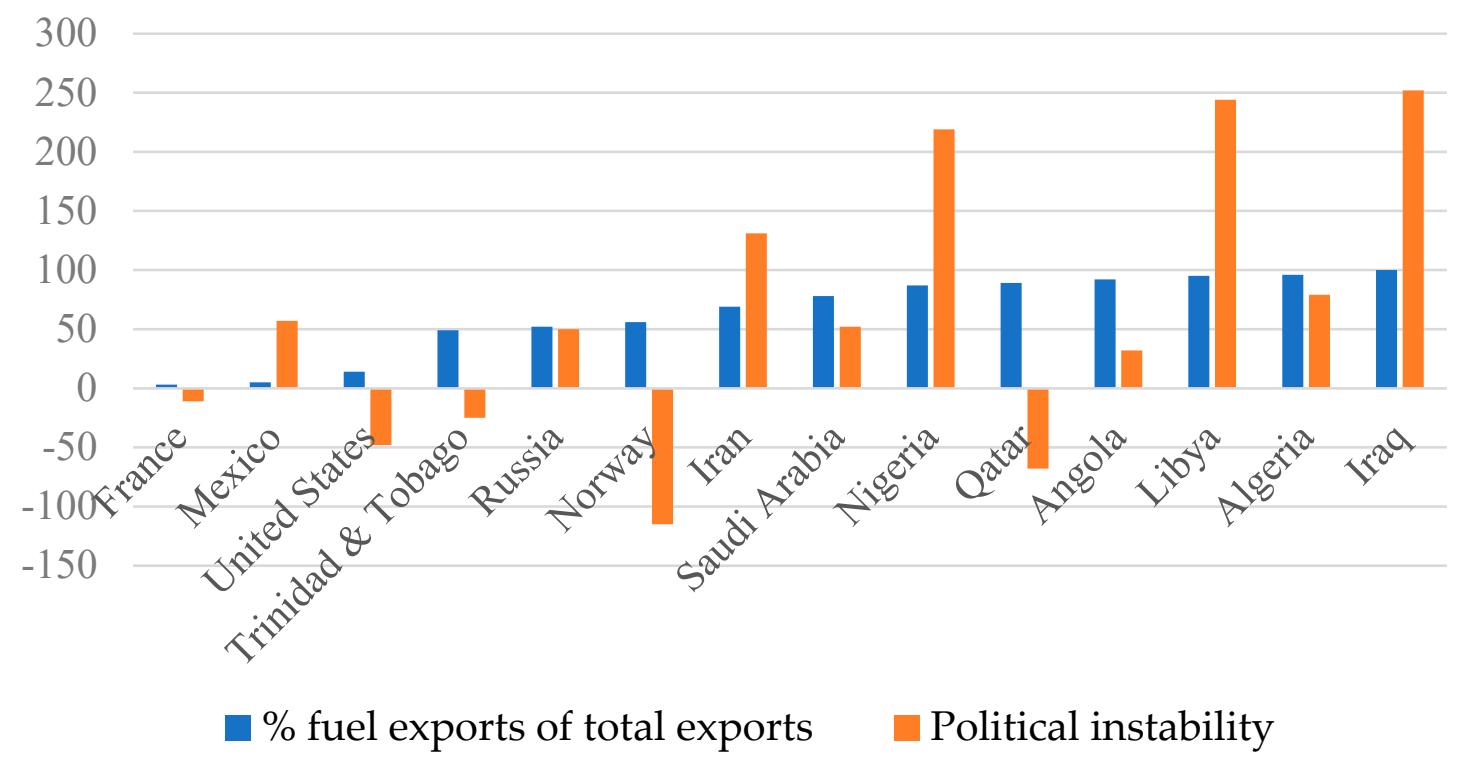

Figure 6. Fuel exports (\% merchandise exports) vs. political instability per country. Source: own elaboration from Chatham House \& World Bank.

\section{Discussion}

Spain presents a vast potential for the development of RE. Previous incoherent taxation policies regarding renewable energies in the wake of the 2008 financial crisis discouraged investments in solar power. However, ER's installed power has continued to grow since 2015 against the halt or dismantling of conventional energy generation facilities, to the extent of doubling renewable installed power over Spain's maximum demand. However, the percentage of installed solar power contrasts with its untapped potential, especially in the low populated inland areas, and the southern part of the country (in cities such as Huelva and Almería) that receive more than 3000 sunlight hours a day. Wind power is consolidating as the main environmentally friendly energy source, and putting Spain at the forefront of the world's wind power generation capacity with $26 \mathrm{GW}$. While this has translated into a modest growth in renewable production, gas-dependent systemsnamely combined cycles-and nuclear energy continue to dominate electricity production as they are highly reliable backup sources and can easily replace coal. Hence, the steep decline in the use of coal experienced in 2018 and 2019 must be underscored, although the closure of the very last coal mines in December 2019 had already been stipulated in the Council Decision 787/2010 regarding state financial aid for uncompetitive coal mines. In addition, seven out of fourteen coal-fired power stations shut down in mid-2020 as the taxes on coal emissions no longer render the exploitation of said fuel cost-efficient. In this respect, the Spanish diligence on working towards achieving an eventual coal phase-out in a near-future (as in other countries, no specific date has been set to stop using energy derived from coal) contrasts with the fierce resistance from other coal-intensive countries such as Poland, the Czech Republic, or Germany, to a lesser extent.

When it comes to electricity, the data is inconclusive. Although there seems to be a correlation between the increase in the number of renewable electricity generators and the increase in the capacity for cross-border exchange, it should also be pointed out that most of the newly installed capacity pertains to the combined cycle, and despite the substantial investments in solar power, these have not yielded significant results yet. In addition, we can infer from the data related to the GOs that Spanish RES has not awakened much interest in the neighboring Member States. These already have access to cheap, low-carbon 
energy, because the renewable generating park is quite competitive in the case of Portugal and France still relies on nuclear power.

While the objective of a greater RES penetration should not be to bet on exports at all costs, it is logically intended to reduce imports to more reasonable levels, which is not happening at this stage. Despite the renewable potential, especially regarding solar power, Spain remains a net importer of electricity, and this is largely due to its high prices in relation to adjacent countries.

Regarding electricity interconnections, it is worth elaborating on Morocco's case. Spain seems to have overcome the misgivings that perceived it as a threat to the development of indigenous RES due to the need to integrate them and the inability to import to the rest of Europe because of insufficient interconnections [12]. Morocco has devised a renewable energy plan, although at a slower rate than its energy needs. The latest Moroccan export balance is an anomaly in a country whose net balance has historically been an importer and forced Spain to increase the volume of exports to meet its growing demand. Although the data is not transparent as it is not feasible to find out the origin of such electric energy, the change in the energy balance with Morocco in the last year suggests that certain companies have taken advantage of its neighbor status outside the EU to import cheap energy from a recently inaugurated coal-fired power plant in Sufi, just $600 \mathrm{~km}$ southwards from Spain. Since such electricity is not subject to the Emissions Trading System, this allows energy to be imported at a much lower price than if it were generated in Spain; this dissociation between energy activity and the goals of decarbonization betrays the Deal's green oath ("Do no harm"). Even if it does not negatively affect a greater exchange of electricity, it is thus self-defeating in the path towards a $100 \%$ renewable system.

In general, the projects presented to build up to four interconnections clearly point towards an electric regionalization, although this is occurring slowly. A key geopolitical ramification regarding interconnections is the geopolitical situation of Ceuta and Melilla. Despite the fluid economic and political relations between the two countries, the historical claims on both Spanish autonomous cities make them less vulnerable if they are decoupled from the Moroccan network, which on the other hand undermines the guarantee of supply. This comes in stark contrast with the assumption that a greater grid interconnection would minimize strategic behavior, since the risk of retaliation by other grid members is greater than the benefit, and there is no assurance that the country involved will not subtly threaten this by claiming supply system failures.

As for Spain's preference in fossil fuel supply countries, in light of the variations in imports by country, it is difficult to assert that there has been a shift towards producers with greater political stability since the signing of the Paris Agreement. The assumption was that the political instability of key producers would divert the fossil fuel demand to other countries anticipating a future exacerbation of the situation, as they would no longer receive sufficient fossil fuel revenues. However, out of the 12 producer countries covered in the study, only four have an acceptable index of political stability: France, Norway, the United States, and Qatar. Except for Saudi Arabia and Nigeria, the rest of the OPEC members show higher rates of instability and tend to be associated with little room to maneuver during prices surges, yet this has not resulted in reduced imports. In fact, in the case of Libya, although supply was disrupted in 2011 during the Arab Spring, it has been the country that has grown the most in the percentage of imports despite the unfolding of the civil war. The fact that Spain does not rely on a single country for more than $30 \%$ of its total imports makes diversification the finest mechanism for mitigating the potential vulnerability resulting from the greater political instability of a particular exporter.

However, some of these countries that show stability despite their high dependence on hydrocarbons are anticipating the impact of their future decline and are preparing for it. For instance, Saudi Arabia, foreseeing the risks of the renewable transition, began to diversify its economy through the Vision 2030 Plan while introducing RES at the domestic level and privatizing sectors such as transport or health, or the flotation of Aramco in order to mitigate the impact. In the case of Norway, it is more than likely that in the future its 
income from the sale of hydrocarbons will drop significantly; however, having kept oil income separate from domestic consumption to avoid precisely the Dutch disease.

The case of Iran is unique, given that imports were brought to a halt due to disputes with the United States under threat of economic sanctions. Therefore, no substantial changes can be observed as a result of the level of their domestic political instability, at least with respect to oil exporters. Ratios are a historical milestone given that it is generally cheaper to transport the hydrocarbon through already installed pipelines than through ships from more distant locations. Export patterns point to greater dependence of the Americas on Africa. The entry of countries such as the United States into the sources of supply to Spain with shale gas, which is cheaper than Algerian gas, and the transport of LNG is more flexible.

The sharp downturn in imports from Algeria could also be attributed to political instability, legislative paralysis following Bouteflika's withdrawal, and the inability of the new government to quell the protests, shrinking the demands to levels of 2010, this is, down to $33 \%$. In addition to these recent geopolitical uncertainties, extraction costs in the Eastern Mediterranean are much higher than in Russia or the United States. Nonetheless, in 2020 we witnessed how Naturgy struck a deal with Sonatrach to review their contract. At first, such an agreement may seem mutually beneficial by achieving more affordable prices for Spanish consumers and ensuring business continuity for Algerian gas for the next 10 years with its third main importer. Yet this rapprochement with the Algerian giant gas supplier may cause a rift with Morocco due to their long-standing regional rivalry, and the latter could attempt to coerce Spain through other means, such as border control, notably turning a blind eye to the reactivation of immigration routes to the Canary Islands, or further pressuring Ceuta and Melilla.

Likewise, the abandonment of the European gas projects with which it was intended to improve the interconnection with Algeria and France weakens Spain's position as a hypothetical energy hub by limiting itself to the already existing interconnections. The price of Russian shale gas proves to be more appealing to other MS eventually self-defeating the EU objective of diversifying energy resources away from Russia, which no longer seems to be a concern [45-47]. On the other hand, the solvent regasification capacity of Spain presents the import of LNG as an opportunity to exploit this excess capacity.

\section{Conclusions}

As stated at the beginning of this article, the geopolitics of energy transition is a complex issue, given that the characteristics of a purely renewable system intertwine with those of traditional fuels.

Despite the recent revival of Spanish RES through the significant boost in installed power, such effort has resulted in a moderate increase in renewable electricity generation, especially due to the variability in raining patterns. However, Spain's thriving wind energy sector is steadily contributing to a greater generation aligned with its National Integrated Plan, yet it is still lagging in the installation of solar power plants.

Regarding electricity trade, the associated agreements for the increase of exchange capacity through the construction of new interconnections with Morocco, France, and Portugal favor the regionalization of energy, in line with the EU goals, although efforts to foster regional cooperation have been informally abandoned after the unsuccessful projects of Euro-Mediterranean.

For a more effective integration of RES into the electricity system, there is a commitment to increase the capacity of electricity interconnections, in opposition to gas ones, at the EU level. That suggests the commitment to move towards more renewable economies is being fulfilled. Although Spain will continue to embrace natural gas in the short to medium term. However, this can only be an excuse to strengthen exchanges, since electrical interconnections are a double-edged sword by allowing the import of cheap electricity that does not necessarily come from renewable energy when other conventional backup sources are used (gas, coal, or nuclear). 
With regard to the second question, although there have been variations in the main suppliers of fossil fuels, it has not been possible to prove the relationship between greater instability and lower consumption from these countries, since it does not yet seem to have an effect on Spain's strategic decisions. In fact, the increase in imports with Libya and the maintenance of imports with the bulk of the OPEC countries is proof of this. It is generally difficult to observe significant changes in Spain's hydrocarbon trade patterns caused by greater political instability in these countries in the short term. The consolidation of Qatar as the main exporter of LNG and the entry of the United States also marks the trend whereby LNG is becoming more important to the detriment of natural gas obtained through pipelines.

Nonetheless, the recent renovation of the agreement regarding Algerian gas may have far-reaching political consequences in the region by straining relations with Morocco or hindering the Algerian transition towards a greener economy. At the same time, the divergence between Spain's suppliers and those of the rest of the EU will lead to divergence in the perception of priorities. The imposition of border carbon tariffs to extend the greener wave to the EU neighborhood may put a strain in Spanish imports, while being aware of the necessity to manage possible instability in the Mediterranean region. It would thus be desirable to ensure that adequate steps are taken within the Green Deal throughout the duration of such a contract to foster the adoption of diversification measures in order to reduce the negative impact of decreasing oil revenues, coordinating with other main importers.

To date, we may say that is not the development of RES per se which is leading the energy transition, but rather the carbon tariff system. While the influence of the transition on the regionalization of electricity is more evident, it seems that the changes with respect to fossil fuels will be slow despite the bar set by the Commission. It will be necessary to wait for a reasonable time to observe how these commitments materialize in a way that responds to a decrease in hydrocarbon imports.

It should also be noted that other factors may lead to diverging energy scenarios such as rapid innovation in storage that would enable countries to accumulate their energy or the climate strategy devised by the newly elected US President Joe Biden. Despite the progress being made in the integration of $\mathrm{RE}$, the challenges arising will largely remain quite similar to those of traditional geopolitics.

Author Contributions: Conceptualization, M.d.P.-G., J.A.P.-R. and A.S.-B.; methodology, M.d.P.-G., A.S.-B. and J.A.P.-R.; writing-Original draft, M.d.P.-G.; writing-Review and editing, A.S.-B.; funding acquisition, J.A.P.-R. All authors have read and agreed to the published version of the manuscript.

Funding: This research received no external funding.

Institutional Review Board Statement: Not applicable.

Informed Consent Statement: Not applicable.

Data Availability Statement: Not applicable.

Acknowledgments: Research supported by GESCE-URJC and TRANS-REAL LAB-UVA.

Conflicts of Interest: The authors declare no conflict of interest.

\section{References}

1. Del Pino-García, M. Geopolítica de las energías renovables: ¿panacea o placebo? Implicaciones de la transición energética en España. Global Strategy Report, 49/2020. Available online: https: / global-strategy.org/geopolitica-de-las-energias-renovables-panaceao-placebo-implicaciones-de-la-transicion-energetica-en-espana/ (accessed on 6 November 2020).

2. Heredia, J.; Sánchez-Bayón, A. The European Transition to a Green Energy Production Model. Small Bus. Int. Rev. 2020, 4, 39-52. [CrossRef]

3. Vindel, J.M.; Trincado, E.; Sánchez-Bayón, A. European Union Green Deal and the Opportunity Cost of Wastewater Treatment Projects. Energies 2021, 14, 1994. [CrossRef]

4. VV.AA. IPCC Special Report “Global Warming of $1.5^{\circ} \mathrm{C}^{\prime}$; IPCC: Geneva, Switzerland, 2018. Available online: https://www.ipcc.ch/ sr15/ (accessed on 15 November 2020). 
5. European Parliament Resolution of November 28, 2019 on the Climate and Environment Emergency. Available online: https: / / www.europarl.europa.eu/doceo/document/TA-9-2019-0078_EN.html (accessed on 6 November 2020).

6. European Commission. Communication from Commission to the European Parliament, the European Council, the Council, the European Economic and Social Committee and the Committee of the Regions "The European Green Deal" COM/2019/640 Final. Available online: https:// eur-lex.europa.eu/legal-content/EN/TXT/?uri=COM\%3A2019\%3A640\%3AFIN (accessed on 6 November 2020).

7. Ministerio de Transición Ecológica. Plan Nacional Integrado de Energía y Clima 2021-2030. Available online: https://www. miteco.gob.es/images/es/pnieccompleto_tcm30-508410.pdf (accessed on 6 November 2020).

8. Bagus, P.; Peña-Ramos, J.A.; Sánchez-Bayón, A. COVID-19 and the Political Economy of Mass Hysteria. Int. J. Env. Res. Public Health 2021, 18, 1376. [CrossRef] [PubMed]

9. Huerta de Soto, J.; Sánchez-Bayón, A.; Bagus, P. Principles of Monetary \& Financial Sustainability and Wellbeing in a Post-COVID19 World: The Crisis and Its Management. Sustainability 2021, 13, 4655. [CrossRef]

10. Global Carbon Project. Available online: https:/ / www.globalcarbonproject.org/ (accessed on 6 November 2020).

11. European Commission. The European Green Deal Sets out How to Make Europe the First Climate-Neutral Continent by 2050, Boosting the Economy, Improving People's Health and Quality of Life, Caring for Nature, and Leaving no One Behind. Available online: https: / /ec.europa.eu/commission/presscorner/detail/e\%20n/ip_19_6691 (accessed on 6 November 2020).

12. Escribano, G.; Lázaro, L.; Lechón, Y.; Oltra, C.; Sala, R. Geopolitical Context for CSP in Europe; MUSTEC Project; Real Instituto Elcano: Madrid, Spain, 2019. Available online: https://mustec.eu/sites/default/files/reports/MUSTEC_\%20D6.4\%20Geopol_ context_for_CSP_in_EU.pdf (accessed on 6 November 2020).

13. Overland, I.; Bazilian, M.; Uulu, T.; Vakulchuk, R.; Westphal, K. The GeGaLo Index: Geopolitical Gains and Losses after Energy Transition. Energy Strategy Rev. 2019, 26, 100406. [CrossRef]

14. Sánchez-Bayón, A. Renewal of business \& economic thought after the globalization. Bajo Palabra 2020, 24, 293-318. [CrossRef]

15. Sánchez-Bayón, A.; Trincado, E. Business and labour culture changes in digital paradigm. Cogito 2020, 12, $225-243$.

16. Cohen, S.B. Geopolitics: The Geography of International Relations; Rowman \& Littlefield: Lanham, MD, USA, 2014.

17. Yergin, D. Ensuring Energy Security. Foreign Aff. 2006, 1. Available online: //www.foreignaffairs.com/articles/2006-03-01 / ensuring-energy-security (accessed on 6 November 2020). [CrossRef]

18. Paltsev, S. The Complicated Geopolitics of Renewable Energy. Bull. At. Sci. 2016, 72, 390-395. [CrossRef]

19. Hubbert, M.K. Energy Resources. A report to the Committee of National Resources; The National Academies Press: Washington, DC, USA, 1962.

20. International Energy Agency. Renewable Energy into the Mainstream. Available online: https://library.um.edu.mo/ebooks/b1 362376x.pdf (accessed on 6 November 2020).

21. Vakulchuk, R.; Overland, I.; Scholten, D. Renewable Energy and Geopolitics: A review. Renew. Sustain. Energy Rev. 2020, 122, 109547. [CrossRef]

22. Peters, S. Courting Future Resource Conflict: The Shortcomings of Western Response Strategies to New Energy Vulnerabilities. Energy Explor. Exploit. 2002, 20, 29-60. [CrossRef]

23. Stevens, P. The Geopolitical Implications of Future Oil Demand; Chatham House: London, UK, 2019.

24. Escribano, G. ¿Hacia una Nueva Geopolítica Para el Sector Energético? In Proceedings of the Conference Riesgo País de Coface, Madrid, Spain, 28 May 2019.

25. Scholten, D. (Ed.) Geopolitics of Renewables; Springer: Cham, Switzerland, 2018.

26. Cherp, A.; Adenikinju, A.; Goldthau, A.; Hernandez, F.; Hughes, L.; Jewell, J.; Vakulenko, S. Energy and Security. In Global Energy Assessment: Toward a Sustainable Future; Johansson, T.B., Nakicenovic, N., Patwardan, A., Eds.; Cambridge University Press: Cambridge, UK, 2012; pp. 325-383.

27. Sweijs, T.; de Ridder, M.; de Jong, S.; Oosterveld, W.; Frinking, E.; Auping, W.; Coelho, R.; Bylappa, J.; Ilko, I. Time to Wake up: The Geopolitics of EU 2030 Climate and Energy Policies; The Hague Center for Strategic Studies: The Hague, The Netherlands, 2014.

28. Stegen, K. The Risks and Rewards of Renewable Energies. In New Realities: Energy Security in the 2010s and Implications for the US Military; Strategic Studies Institute: Washington, DC, USA, 2014.

29. Escribano, G. Energías Renovables y Renovación de la Geopolítica; Instituto Español de Estudios Estratégicos-Ministerio de Defensa: Madrid, Spain, 2017; pp. 21-57.

30. Escribano, G.; Touzo, L. Balancing Geopolitics with Green Deal Recovery. Real Instituto Elcano 2020. Available online: http:/ / www.realinstitutoelcano.org/wps/portal/rielcano_en/contenido?WCM_GLOBAL_CONTEXT=/elcano/elcano_in/ zonas_in/ari95-2020-escribano-lazaro-balancing-geopolitics-with-green-deal-recovery (accessed on 7 January 2021).

31. Escribano, G. La Seguridad Energética Española en un Escenario en Transición. Energía Y Geoestrateg. 2014, 116, 93-126.

32. International Energy Agency. Available online: https://www.iea.org/reports/world-energy-outlook-2019/renewables (accessed on 6 November 2020).

33. Scholten, D.; Bosman, R. The Geopolitics of Renewables; Exploring the Political Implications of Renewable Energy Systems. Technol. Forecast. Soc. Chang. 2016, 103, 273-283. [CrossRef]

34. Scholten, D. An Introduction and Expectations in the Geopolitics of Renewable Energies. In The Geopolitics of Renewable Energies; Scholten, D., Ed.; Springer: Berlin/Heidelberg, Germany, 2018; pp. 1-36. 
35. Carbajo, A. La Integración de las Energías Renovables en el Sistema Eléctrico. Documento de Trabajo; Fundación Alternativas: Madrid, Spain, 2012.

36. Red Eléctrica de España-REE. Available online: https://www.ree.es/es/red21/refuerzo-de-las-interconexiones (accessed on 6 November 2020).

37. Estrategia de Seguridad Energética Nacional 2015. Available online: https://www.dsn.gob.es/sites/dsn/files/estrategia\%20de\% 20seguridad\%20energetica\%20nacional.pdf (accessed on 15 November 2020).

38. European Parliament. 2020. Available online: https://ec.europa.eu/energy/topics/infrastructure/electricity-interconnectiontargets_en (accessed on 11 November 2020).

39. Commission Expert Group on Electricity Interconnection Targets, towards A Sustainable and Integrated Europe. 2017. Available online: https:/ / ec.europa.eu/energy/sites/ener/files/documents/report_of_the_commission_expert_group_on_electricity_ interconnection_targets.pdf (accessed on 11 November 2020).

40. Departamento de Seguridad Nacional. Available online: https://www.dsn.gob.es/es/actualidad/sala-prensa/seguridadenerg $\%$ C3\%A9tica-cuarta-lista-proyectos-inter $\%$ C3\%A9s-com $\% C 3 \% B A n$ (accessed on 12 November 2020).

41. Red Eléctrica de España. Available online: https:/ / www.ree.es/es/datos/generacion/estructura-renovables (accessed on 6 November 2020.).

42. CNMC. Informe Estadístico Sobre la Aprobación de Garantías de Origen. Available online: https://www.cnmc.es/consultaspublicas/energia/ (accessed on 6 November 2020).

43. Unión Española Fotovoltaica (UNEF). Garantías de Origen. Available online: https://unef.es/wp-content/uploads/dlm_ uploads/2019/07/20190702_informe-unef-garantias-de-origen.pdf (accessed on 6 November 2020).

44. CORES. Available online: https://www.cores.es/es/estadisticas (accessed on 6 November 2020).

45. Peña-Ramos, J.A. The Impact of Russian Intervention in Post-Soviet Secessionist Conflict in the South Caucasus on Russian Geo-energy Interests. Int. J. Confl. Violence 2017, 11, 1-13.

46. Peña-Ramos, J.A.; Amirov-Belova, D. The Role of Geo-Energy Interests of Russia in Secessionist Conflicts in Eastern Europe. Int. J. Oil Gas Coal Technol. 2018, 18, 485-511. [CrossRef]

47. Peña-Ramos, J.A.; Bagus, P.; Amirov-Belova, D. The North Caucasus Region as a Blind Spot in the "European Green Deal": Energy Supply Security and Energy Superpower Russia. Energies 2021, 14, 17. [CrossRef] 